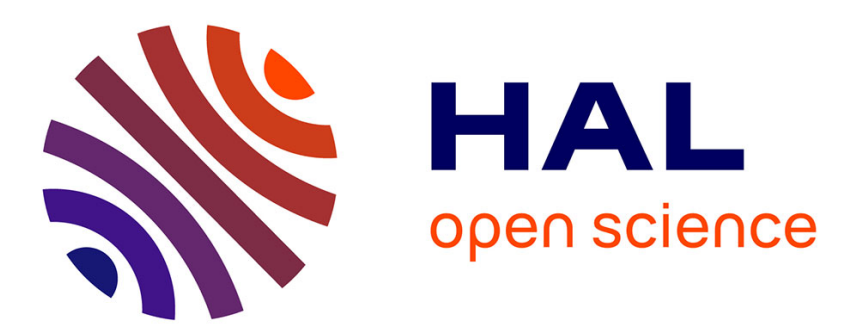

\title{
Use of LCA to evaluate the environmental benefits of substituting chromic acid anodizing (CAA)
}

\author{
Erwan Harscoet, Daniel Froelich
}

\section{To cite this version:}

Erwan Harscoet, Daniel Froelich. Use of LCA to evaluate the environmental benefits of substituting chromic acid anodizing (CAA). Journal of Cleaner Production, 2007, 16 (12), pp.1294-1305. 10.1016/j.jclepro.2007.06.010 . hal-01205598

\section{HAL Id: hal-01205598 \\ https://hal.science/hal-01205598}

Submitted on 25 Sep 2015

HAL is a multi-disciplinary open access archive for the deposit and dissemination of scientific research documents, whether they are published or not. The documents may come from teaching and research institutions in France or abroad, or from public or private research centers.
L'archive ouverte pluridisciplinaire HAL, est destinée au dépôt et à la diffusion de documents scientifiques de niveau recherche, publiés ou non, émanant des établissements d'enseignement et de recherche français ou étrangers, des laboratoires publics ou privés. 


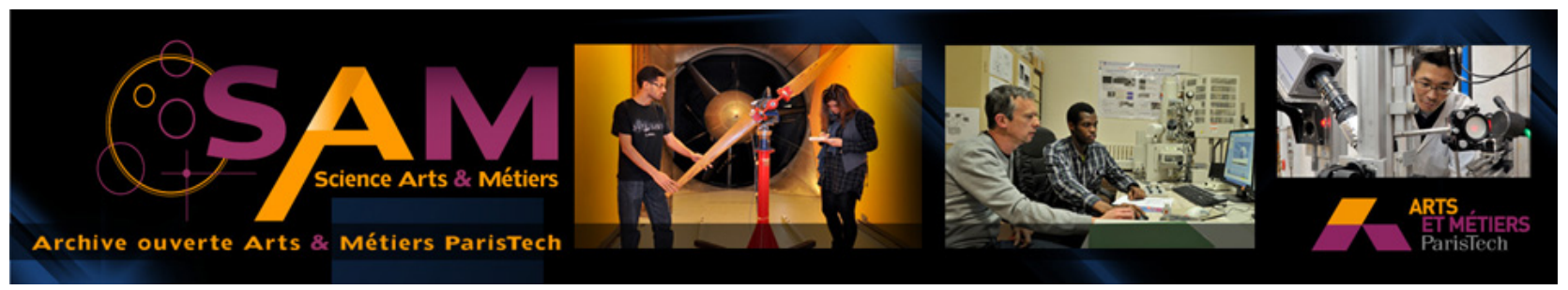

\section{Science Arts \& Métiers (SAM)}

is an open access repository that collects the work of Arts et Métiers ParisTech researchers and makes it freely available over the web where possible.

This is an author-deposited version published in: http://sam.ensam.eu

Handle ID: .http://hdl.handle.net/10985/10178

\section{To cite this version :}

ERWAN HARSCOET, DANIEL FROELICH - Use of LCA to evaluate the environmental benefits of substituting chromic acid anodizing (CAA) - Journal of Cleaner Production - Vol. 16, n¹2, p.1294$1305-2007$ 


\title{
Use of LCA to evaluate the environmental benefits of substituting chromic acid anodizing (CAA)
}

\author{
Erwan Harscoet*, Daniel Froelich \\ Institut ENSAM Chambe'ry - MAPIE, 4 rue du lac majeur, 73375 Le Bourget du Lac, \\ France
}

\begin{abstract}
Chromic acid anodizing processes are currently being replaced in many industrial sectors because of the recognized adverse effect on the environment and health of used hexavalent chromium compounds. The environmental impacts of the existing processes must, however, be quantified in order to constitute a baseline against which the environmental performance of potential alternative options could be compared. The whole life cycle of the process should also be taken into account to ensure that the possible chosen solution for eliminating or lowering chromium (VI) emissions would not drastically damage the overall process performance in other environmental areas. In our study, we used a simplified life cycle assessment methodology that only took into account the key environmental issues of the considered industrial sector. Both the scope and the data needs were reduced by focusing only on significant flows and by using a generic database for steps other than the anodizing one. A precise literature review was carried out to evaluate bath atmospheric emissions. The results of the performed assessment confirmed that the only way to efficiently deal with hexavalent chromium compounds is to substitute the electrolyte used in the bath as the most Cr(VI) emissions are caused by other stages than the main one. Other specific issues, such as water and energy consumptions have, nevertheless, to be studied throughout the whole life cycle of the chemical substitute to monitor performance against CAA.
\end{abstract}

Keywords: Chromic acid anodizing; Atmospheric emissions; Surface treatment; Hexavalent chromium; Simplified LCA; Chemical substitution; Significant flows

\section{Introduction}

Chromium (VI) compounds are currently subject to strong regulatory pressure mainly because of their adverse effect on the environment and human health. Some of their specific uses are now drastically restricted or even forbidden for some industrial processes and sectors. Moreover, general European regulations or directives such as $\mathrm{RoHS}^{1}, \mathrm{COMAH}^{2}$ and especially $\mathrm{REACH}^{3}$, may have huge cost impacts for the

\footnotetext{
* Corresponding author. Tel.: +33 (0) 479262685 .

E-mail address: erwan.harscoet@ensam.eu (E. Harscoet).

${ }^{1}$ Directive 2002/95/CE on the restriction of the use of hazardous substances in electrical and electronic equipment.

${ }^{2}$ Control of major accident hazards regulations which implement directive 2003/105/EC.

${ }^{3}$ Proposal of a regulation of the European parliament and of the council concerning the registration, evaluation, authorisation and restriction of chemicals (2003).
}

industry concerned and implementing alternatives would certainly become profitable. Estimating the avoided amount of chromium (VI) released into the environment by a chemical substitution would then constitute interesting information, but it is clear that only focusing on the substance's use phase will not provide the most valuable results.

Chromic acid anodizing processes involve the use of chromium trioxide ${ }^{4}$ in the form of various species which are mainly made of chromic acid when mixed with water. Some chromium (VI) atmospheric emissions or discharges to water may be generated during this surface treatment process and must be quantified. However, the whole life cycle of the chemical used shall be studied as chromium trioxide is produced from other hexavalent compounds, meaning that other

\footnotetext{
${ }^{4}$ Chromium trioxide is a hexavalent chromium compound which is also named chromium (VI) oxide, chromic anhydride or inadequately chromic acid.
} 
processes may be at the source of $\mathrm{Cr}(\mathrm{VI})$ emissions. Finally, other environmental impacts should be considered in order to constitute a precise baseline that will be compared to the different substitution alternatives.

\section{Methodology deployed}

Life cycle assessment methodologies are now widely used when evaluating impact of products, processes and devices [1]. Some tools focus on design improvements whereas others are more suitable to establish environmental profiles, the latter being more in line with our study. The required detail levels and the perimeter considered often vary according to the project, and one of the most challenging points of LCA is the identification of the "key issues" that must be investigated in detail. Different meanings may be associated to this term [2]. First, key issues can simply be defined as aspects of LCA that require more detailed research to reach a solid conclusion. Secondly, they can also be viewed as areas in which product and process improvements lead to the highest environmental gain. A third meaning of the term refers to the life cycle stages or emissions/extractions that contribute heavily to the total impacts of a product or system.

Some methodologies are designed so that the studies focus only on data that will be effectively useful in achieving the previously defined objectives. In these simplified LCA approaches (described more precisely farther on), the minimum set of information needed to draw reliable and solid conclusions is collected. It should, however, be kept in mind that "usually, guidelines for deciding whether the level of detail suffices, and if not, at which points to improve on data quality, lack" [2].

We chose in our study to conduct a simplified life cycle assessment, based on ISO 14040 standard series [3], of an aluminium anodizing process using chromium trioxide.

We first consider the "Functional Unit" and "Scope" definition phases.

The perimeter of the life cycle assessment must be defined. But before, it should be kept in mind that the final goal of this work is to produce a baseline to be used as the comparison reference for the evaluation of the environmental performance of any substitution process. Indeed, remember that the chromium trioxide used in the considered aluminium conversion process should be replaced by another substance primarily because of its toxic properties and the associated regulatory pressure. The functional unit chosen in our life cycle assessment concerns the treatment of a specific aluminium surface area and includes the corrosion resistance performance of the anodized aluminium. Each physical flow considered in our study is then linked to this functional unit.

Usually, the functional unit chosen is associated with a spatial or temporal context [4]. We here consider both quantitative and qualitative parameters. This is why the functional unit is defined as a specific surface area protected for a certain period of time and under specific operating conditions. The specific surface area has been fixed at $10,000 \mathrm{~m}^{2}$ of anodized aluminium. The corrosion resistance performance, which is dictated by the environment in which aluminium parts operate, is one of the highest requirement in our case study, as treated metal is operated for decades under extreme climatic conditions (hot, cold and severe cold). The functional unit finally impose that the properties provided by the initial anodizing process are effective during the whole life cycle of metal parts.

It should, nevertheless, be noted that aluminium is actually painted to ensure full corrosion protection, and that, unlike the anodizing process, the painting impose periodic checking and maintenance actions.

Then, we describe how the phases dedicated to the "Life Cycle Inventory" and "Environmental Inputs/Outputs" collection are organized.

We decided to limit the field of our investigation to what can be considered as the main Environmental, Health and Safety (EHS) issues of a chromic acid anodizing bath [5]. We then chose to estimate parameters that are linked to the so-called "significant environmental aspects" of traditional surface treatment processes. In our study, we define them as parameters that strongly contribute to the total impacts of a system, in line with the third meaning of "key issues of an LCA". A document published by the European Commission is at the source of the identification of the categories that we focus on in our study. In the "EC Best Available Technologies Reference (BREF) document for the surface treatment of metals and plastic" [6] major issues of this industrial sector are indeed clearly described. First, surface treatments are traditionally associated with high water consumption. The chemicals used may also be dangerous for the environment and especially for surface and ground waters as well as for soils. Metals included in water discharges, in the end, constitute waste that must be treated using specific disposal or recovery processes. Then, possible formed aerosols, fumes, dusts and pollutants may be released into the plant air or directly into the atmosphere. Finally, energy and natural resource consumptions are considered as being significant in the surface treatment sector.

To summarise, the aspects that we decided to include in our life cycle assessment concern six different categories.

- Water consumption

- Energy consumption

- Hazardous substances released into the environment

- Waste generation

- Non-renewable resource consumption

- $\mathrm{CO}_{2}$ emissions

Energy consumptions, in our study, include not only electric and thermal energies used in the processes, but also energy used for raw materials transportation. $\mathrm{CO}_{2}$ emissions are mainly deduced from energy consumptions, but some of them are directly coming from chemical reactions that occur in some industrial processes. That is why, even if energy and $\mathrm{CO}_{2}$ emissions categories are not very independent, we choose to keep them distinct. Moreover, as $\mathrm{CO}_{2}$ emission factors, applied to the different kind of energy consumptions assessed, significantly vary among sources, some useful 
information may be deduced when switching from one category to the other.

Existing simplified life cycle assessment methodologies may take various forms according to the targeted objectives. Basically, the simplified process may aim at reducing the scope of the study and/or at lowering the data needs. The exclusion of some life cycle stages or product levels may for instance help to reduce the scope whereas the use of an available generic database reduces data needs [7]. The following simplified approaches are the most well-known ones [8].

- Carrying out only the assessment of flows without linking them to their precise contributions to environmental impacts, such as global warning or ozone depletion (impact assessment/characterization).

- Considering only one precise criterion that may for example be energy consumption.

- Assessing only specific environmental problems and product life cycle stages.

In our approach, we mix the first and third methodologies by considering only flows related to the chosen categories and that may be considered as significant ones. The selection of the significant flows in our inventory stage is done on the basis of the methodology defined in the ISO documentation [3]. In which, simple criteria such as energy or mass are chosen and flows that contribute to each criterion, and that are superior to a fixed threshold, are kept as significant. Other methodologies not described here, such as the Relative Mass-Energy-Economic (RMEE) method for boundary selection or the input/output analysis shortcuts, may also be used [4].

Our significant flows identification method is based on very simple principles: we consider the use stage (the aluminium anodizing process) as the initial one. Every input and output linked to this activity are then assessed and classified into the category that they are linked to (water consumption, waste generated, etc.). A flow will then be considered as being significant if it represents more than $5 \%$ of the category in which it is included. The sum of all the significant flows of one category shall also account for more than $95 \%$ of total flows of the category $[9,10]$. Finally, every other stage resulting from any significant inputs or outputs will be considered in the same way as the initial use stage.

Typical life cycle phases, we included in our assessment, are shown in Fig. 1.

Our specific methodology designed to select which flows are significant, imply the precise assessment of the inputs and outputs of the anodizing stage.

\section{Inputs and outputs of the aluminium treatment phase}

Inputs and outputs of aluminium anodizing have been assessed through a case study that we accurately modeled on an industrial site: a large part of these data then come from real measurements, which is not the case of the other phases considered in our study.

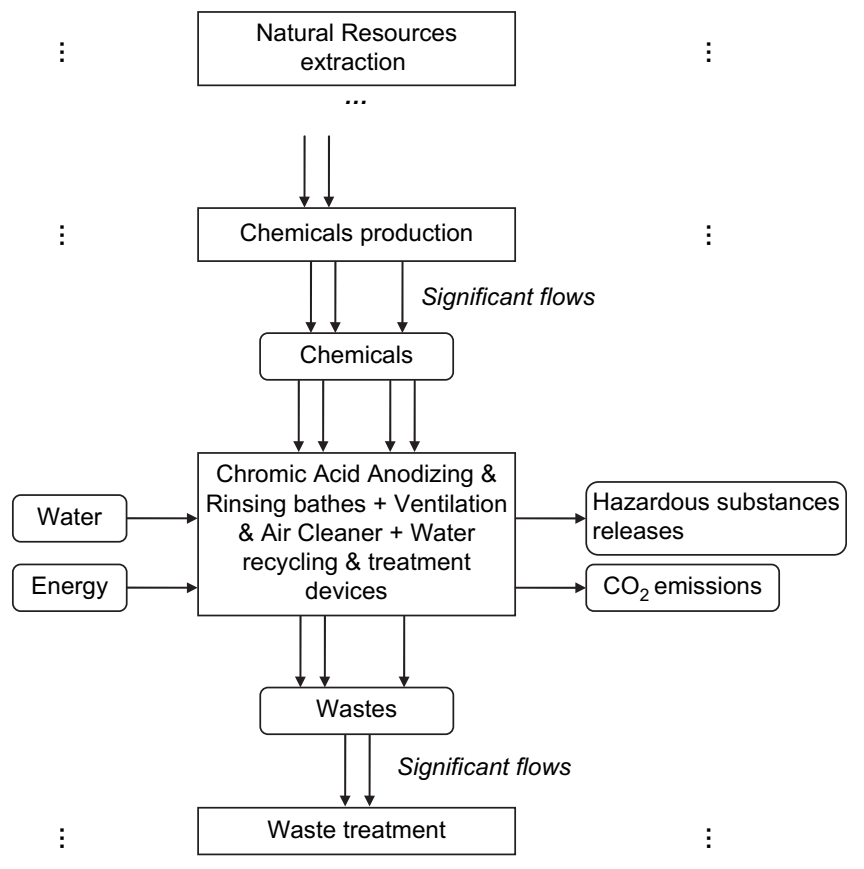

Fig. 1. Simple diagram of the life cycle phases included in our assessment.

The metal surface treatment line integrating the chromic acid anodizing process is briefly described for better understanding. Metal pieces are plunged into a heated treatment bath and some electrical energy is used for the electrolytic treatment. Treated workpieces are then taken into the rinsing bath where some electrolyte solution is dragged out [6] and the cleaned aluminium finally goes through next process which can be another treatment bath or a drying process. Rinsing water is recycled using ionic exchange resins that have to be regenerated with acid and alkaline solutions and this regeneration scheme generates eluates that are concentrated by evaporation. The resulting concentrates are treated externally, whereas the distillates are reused. When the minimum quality

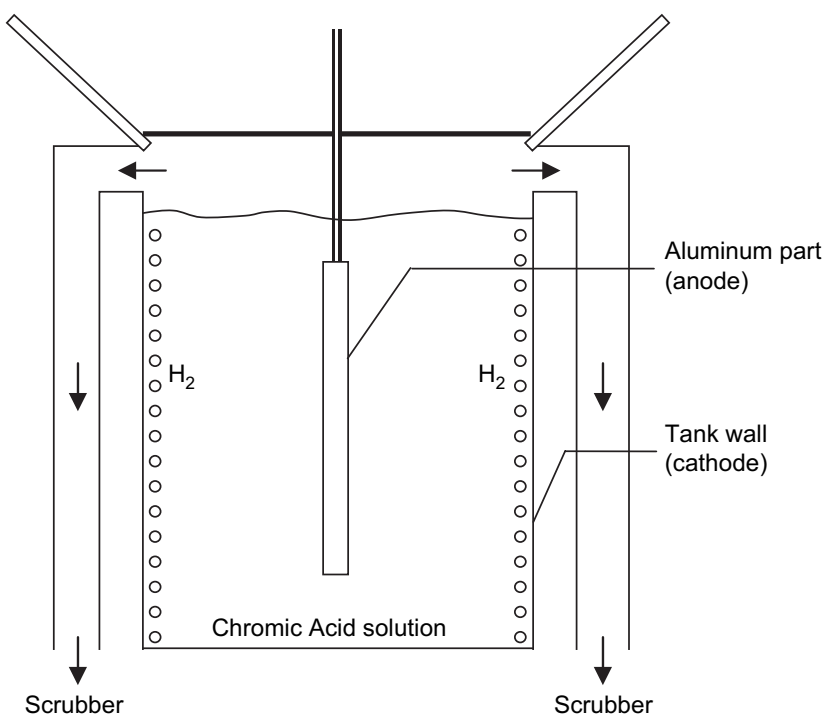

Fig. 2. Formation of hydrogen gas bubble during anodizing. 


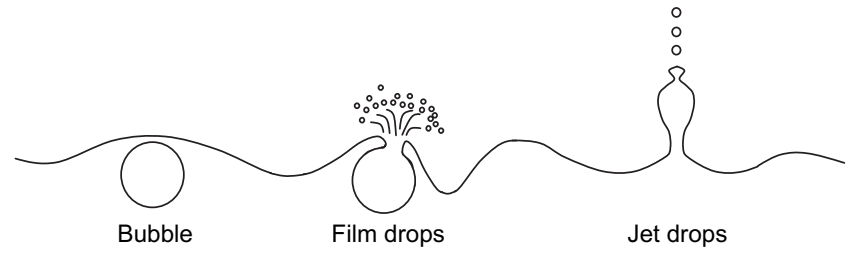

Fig. 3. Formation of hydrogen gas bubble during anodizing.

of the anodizing treatment (characteristics of the alumina layer created on workpieces) is no longer reached, the bath is changed, and the used one is also treated externally. Aerosols emitted during the electrolytic process are collected by the ventilation system and treated within a fume suppressant coupled with a packed-bed scrubber. Cleaned air is then rejected into the atmosphere and water effluents are treated internally. We point out that no water discharge occurs when the considered line is run, since every solid and liquid wastes are stored for external treatment. Inputs and outputs of this main stage comprise.

- Some chromium trioxide and water are used to form the bath (bath renewing, or evaporation and drag outs compensation).

- Thermal energy is used to heat the bath and to concentrate effluents.

- Some sodium hydroxide, sulfuric acid, hydrochloric acid and water are consumed to regenerate the ionic exchange resins and to neutralize effluents.

- Some water is consumed to treat air emissions.

- Used baths and concentrates from the internal treatment plant (evapo-concentrator) constitute externally treated waste.

- All possible emitted aerosols are carefully controlled, collected and treated and some of them are rejected into the atmosphere and into the workplace.

Data was estimated using different methodologies ranging from theoretical formulas to historical statistics. The consistency of all results was checked by comparing them with the true recorded values, with the exception of chromium (VI) emissions because of the lack of available information. Hexavalent chromium emitted during aluminium anodizing should, therefore, be considered as a theoretical value. These theoretical values are nevertheless consistent with on-site control made to ensure that $\mathrm{Cr}(\mathrm{VI})$ concentrations measured in the workplace satisfy regulatory thresholds.
Table 2

Efficiencies of different air cleaning system

\begin{tabular}{ll}
\hline Treatment process & Efficiency (\%) \\
\hline None & 0 \\
Polypropylene balls & 15 \\
Fume suppressant & 96.8 \\
Fume suppressant and polypropylene balls & 98.7 \\
Packed-bed scrubber & 99.5 \\
Fume suppressant and packed-bed scrubber & 99.9 \\
Mesh-pad mist eliminator & 99.7 \\
Packed-bed scrubber and mesh-pad mist eliminator & 99.9 \\
Wet scrubber, moisture extractor and high efficiency & 99.9 \\
particulate air filter & \\
\hline
\end{tabular}

The following paragraph is devoted to the literature review carried out on studies dealing with the aerosol emissions from baths in the surface treatment industrial sector.

Kincaid and Geibig (1998) [11], in an US EPA study, refer to Burgess (1981) [12] who identified aerosols and fumes as the main atmospheric emission sources from electrolytic baths. An aerosol is constituted of solid or liquid particles in suspension in the gaseous phase. Two main aerosol generation sources exist in the surface treatment process.

- The dripping of liquid dragged out by pieces during their transfer.

- Bubbles bursting when they reach the bath surface.

Berglund and Lindh (1988) [13] as well as Cooper et al. (1993) [14], demonstrated that air transfers through the dripping of liquid were negligible compared to the other aerosol source. Kuo and Wang (2002) [15] also underlined that it is the droplet creation following the bubble bursting that most contributes to the transfer of non-volatile compounds from liquid to air. We consider in our study that polluting atmospheric emissions coming from a surface treatment bath come from bubble bursting. It should, however, be noted that bubbles may either come from the bath sparging with air or from the water dissociation that takes place at the electrodes. Robinson et al. (1996) cited by Kincaid and Geibig [11] finally claimed that aerosol generation is far more significant when considering an electrolytic process than for a bath simply mixed by air sparging.

Aerosol generation from an anodizing process was described by Pegman and Pilat (1992) [16]: hydrogen gas is formed on the negatively charged tank walls (cathode) and

Table 1

Source for the assessment of the amount of $\mathrm{Cr}(\mathrm{VI})$ emitted by a chromic acid anodizing bath

\begin{tabular}{llll}
\hline Study & $\begin{array}{l}\text { Type of data/model } \\
\text { available }\end{array}$ & Units used & $\begin{array}{l}\text { Cr(VI) emissions deduced for } \\
\text { the case study considered here }\end{array}$ \\
\hline Berglund et al. & Theoretical abacus & $\mathrm{mg} \mathrm{Cr}(\mathrm{VI}) \mathrm{m}^{-2} \mathrm{~s}^{-1}\left(\mathrm{~m}^{2}\right.$ : cathode size $)$ & $8.15 \mathrm{~g} /$ anodization \\
Pegman and Pilat & Measurements & $\mathrm{mg} \mathrm{Cr}(\mathrm{VI}) \mathrm{m}^{-2} \mathrm{~h}^{-1}\left(\mathrm{~m}^{2}\right.$ : bath area) & $16 \mathrm{~g} /$ anodization \\
& Measurements & $\mathrm{mg} \mathrm{Cr}(\mathrm{VI}) \mathrm{A}^{-1} \mathrm{~h}^{-1}$ & $21.8 \mathrm{~g} /$ anodization \\
US EPA emission factor guide [17] & Emission factor formula & $\mathrm{mg} \mathrm{Cr}(\mathrm{VI}) \mathrm{m}^{-2} \mathrm{~h}^{-1}\left(\mathrm{~m}^{2}\right.$ : bath area) & $11.8 \mathrm{~g} /$ anodization \\
US EPA, experimentation source [17] & Measurements & $\mathrm{mg} \mathrm{Cr}(\mathrm{VI}) \mathrm{A}^{-1} \mathrm{~h}^{-1}$ & $5.1 \mathrm{~g} /$ anodization \\
US EPA, experimentation source [17] & Measurements & $\mathrm{mg} \mathrm{Cr}(\mathrm{VI}) \mathrm{m}^{-2} \mathrm{~h}^{-1}\left(\mathrm{~m}^{2}\right.$ : bath area) & $6.2 \mathrm{~g} /$ anodization \\
\hline
\end{tabular}


Table 3

Inputs and outputs of the aluminium anodizing phase

\begin{tabular}{lcc}
\hline Inputs/outputs & Value & Unit \\
\hline $\begin{array}{l}\mathrm{CrO}_{3} \text { used in new baths and for drag } \\
\quad \text { outs compensation }\end{array}$ & 131.9 & $\mathrm{~g} / \mathrm{m}^{2}$ \\
Water consumed & 13.49 & $\mathrm{~L} / \mathrm{m}^{2}$ \\
Electrical energy consumption & 3.5 & $\mathrm{kWh} / \mathrm{m}^{2}$ \\
Thermal energy consumption & 88.5 & $\mathrm{MJ} / \mathrm{m}^{2}$ \\
$\mathrm{NaOH}$ consumption & 0.1 & $\mathrm{~L} / \mathrm{m}^{2}$ \\
$\mathrm{HCl}$ consumption & 0.049 & $\mathrm{~L} / \mathrm{m}^{2}$ \\
$\mathrm{H}_{2} \mathrm{SO}_{4}$ consumption & 0.011 & $\mathrm{~L} / \mathrm{m}^{2}$ \\
$\mathrm{Cr}(\mathrm{VI})$ emitted by the bath & 0.239 & $\mathrm{~g} / \mathrm{m}^{2}$ \\
$\mathrm{Cr}(\mathrm{VI})$ collected by the ventilation system & 0.227 & $\mathrm{~g} / \mathrm{m}^{2}$ \\
$\mathrm{Cr}(\mathrm{VI})$ released into the workplace & 0.012 & $\mathrm{~g} / \mathrm{m}^{2}$ \\
$\mathrm{Cr}(\mathrm{VI})$ released into the external atmosphere & 0.002 & $\mathrm{~g} / \mathrm{m}^{2}$ \\
Liquid waste generated, used bath and & 3.68 & $\mathrm{~L} / \mathrm{m}^{2}$ \\
$\quad$ concentrates being included & & \\
\hline
\end{tabular}

after the bubbles rise to the liquid surface they burst and emit liquid aerosol droplets which are swept away in the air flowing to the exhaust ducts. Two distinct types of aerosol droplets are generated by the bursting of a gas bubble: liquid film aerosol droplets and liquid jet aerosol droplets, the latter being larger (see Figs. 2 and 3).
We used different methods to estimate the quantity of chromium (VI) compounds emitted during one anodization process of a specific aluminium area. Some use specific formulas or tables while others simply use extrapolations from measurements taken on industrial sites when precise bath characteristics were known (size, temperature, current density, etc.). The results are presented in Table 1.

After careful consideration, it was decided to use the value estimated from the theoretical abacus, as this is the only one taking into account the specific parameters of our case study.

In order to determine the level of emissions released into the atmosphere, we estimated that the efficiency of the ventilation system used is $95 \%$ by using experiment results of a French public organization [18,19]. Some mean efficiencies for different air cleaning systems are presented in Table 2 [17].

We chose in our study to use $99 \%$ efficiency for the air treatment system comprising a fume suppressant and a packed-bed scrubber.

Finally, the inputs and outputs that we assessed for the anodizing process, each related to $1 \mathrm{~m}^{2}$ of aluminium treated, are summarized in Table 3.

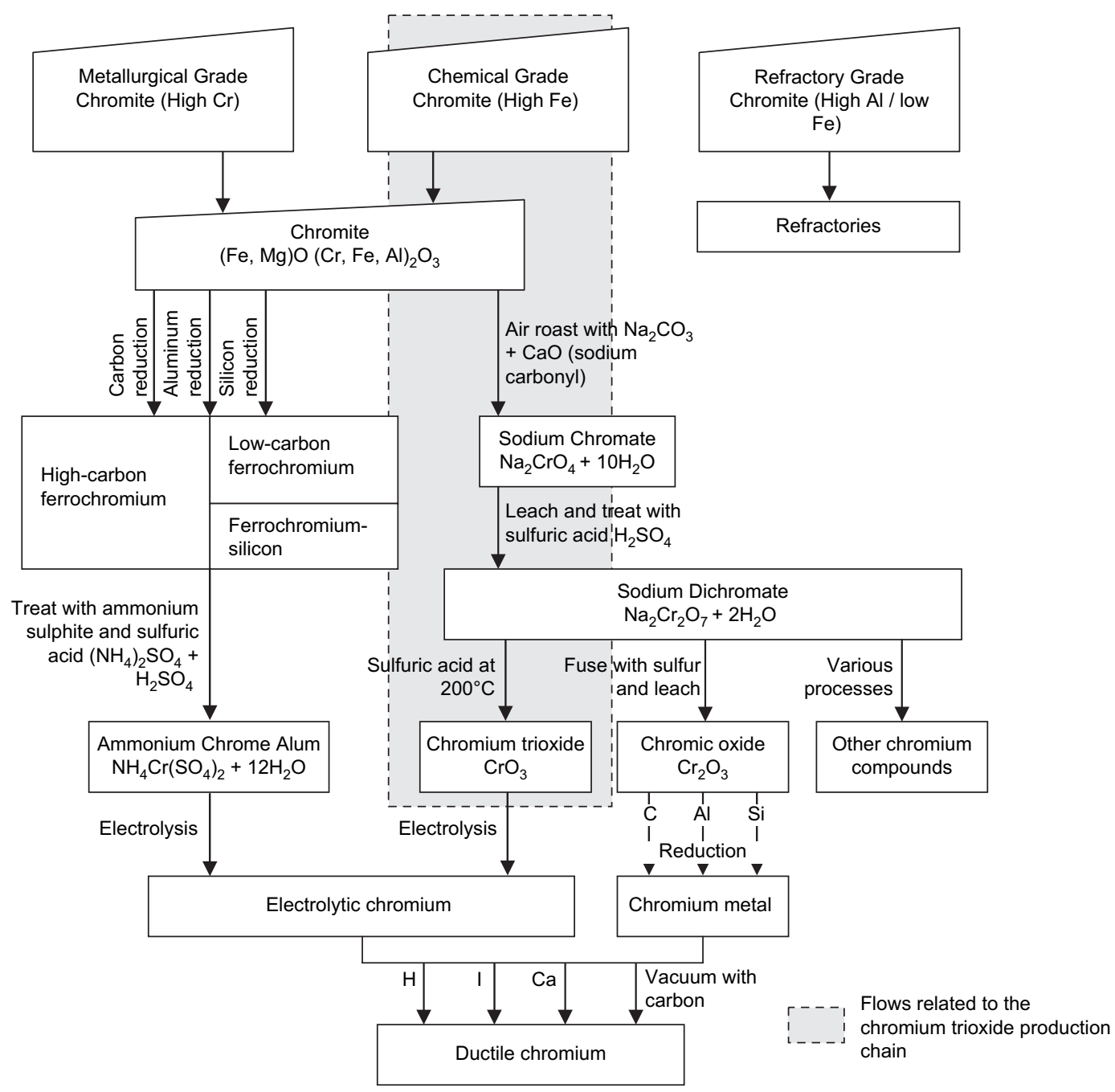

Fig. 4. Steps required for producing chromium trioxide (Source: US EPA). 
We specifically draw attention in our study to the various processes dedicated to the production of the final chemical used in the anodizing bath (which is chromium trioxide).

\section{Production of chromium trioxide, sodium dichromate and sodium chromate}

The stages described in this section need advanced research to be incorporated into the study. The different production steps required for chromium trioxide manufacturing have been identified by isolating them into the global stages related to the production of chromium compounds and metallic chromium [20,21] (see Fig. 4).

We will now briefly describe the sodium chromate, sodium dichromate and chromium trioxide manufacturing processes.

First, chromite ore is crushed, dried and ground to be refined to customer specifications. Then the ground chrome is mixed with soda ash $\left(\mathrm{Na}_{2} \mathrm{CO}_{3}\right)$, lime $(\mathrm{CaO})$ and calcine residue from a previous roasting operation. The mixture is then roasted in a rotary kiln at temperatures of 1100 to $1150{ }^{\circ} \mathrm{C}$

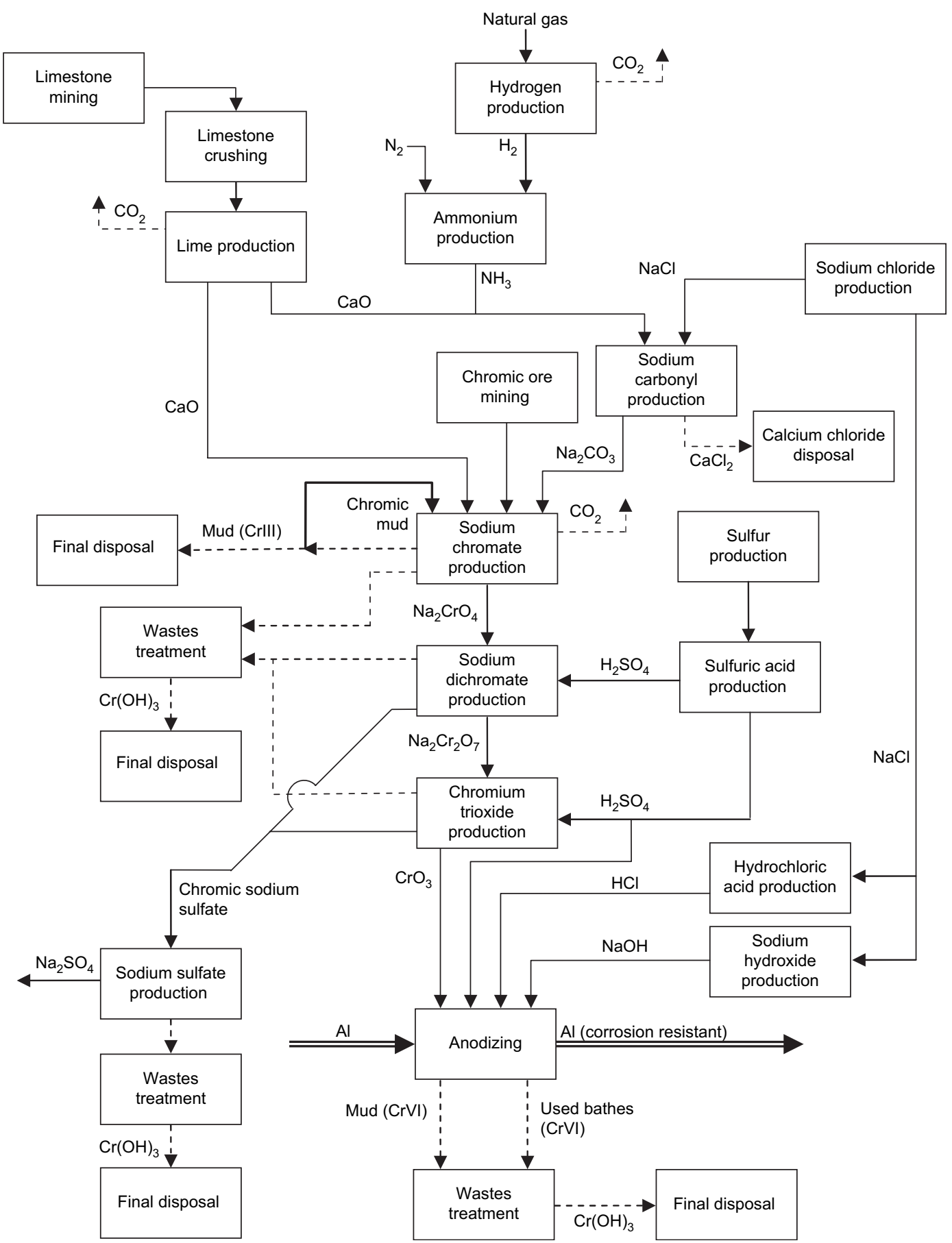

Fig. 5. Significant flows of the chromic acid anodizing process life cycle. 
for roughly $4 \mathrm{~h}$. Oxidation occurs and sodium chromate is produced with the basic reaction being

$$
\begin{aligned}
4 \mathrm{FeCr}_{2} \mathrm{O}_{4}+8 \mathrm{Na}_{2} \mathrm{CO}_{3}+7 \mathrm{O}_{2} \rightarrow & 2 \mathrm{Fe}_{2} \mathrm{O}_{3}+8 \mathrm{Na}_{2} \mathrm{CrO}_{4} \\
& +8 \mathrm{CO}_{2}
\end{aligned}
$$

The kiln is then discharged through a cooler and leached, and the leached calcine is recycled at the raw material mixing station. Some mud is also generated when alumina is precipitated and removed from the refined chromate liquor. The latter is then used to produce sodium dichromate by treatment with sulfuric acid. The sodium dichromate liquor is evaporated and a sodium sulfate by-product is precipitated. The purified and concentrated dichromate liquor is crystallized, put through a crystal centrifuge, dried and packaged.

Chromium trioxide can be produced by mixing sodium dichromate with sulfuric acid in a reactor heated externally and stirred with a sweep agitator and the chemical reaction that takes place is

$\mathrm{Na}_{2} \mathrm{Cr}_{2} \mathrm{O}_{7}+2 \mathrm{H}_{2} \mathrm{SO}_{4} \rightarrow 2 \mathrm{CrO}_{3}+2 \mathrm{NaHSO}_{4}+\mathrm{H}_{2} \mathrm{O}$

Water, chromium trioxide and sodium bisulfate are finally separated and the chromic acid layer is tapped from the reactor and flaked on water-cooled rolls to produce the commercial product.

\section{Overview of significant flows and stages}

We used the methodology previously described to determine which flows and life cycle stages could be considered as being significant in our study (see Fig. 1).

Basically, the inputs and outputs modeled for aluminium anodizing (see Table 3) were considered in the initial step. Then, the Ecoinvent database $[22,23]$ was used to assess consumptions and discharges caused by each stage related to every input and output in the aluminium treatment process. Using the same step-by-step approach for each significant flow allowed us to identify the significant steps of our life cycle assessment.

We drew a diagram adapted from the one constructed by Kowalski et al. [24], who carried out some life cycle assessments of different sodium chromate manufacturing processes, to represent the significant flows and stages of the aluminium anodizing life cycle using chromium trioxide (see Fig. 5).
We chose to use, for sodium chromate production, the average process described by Kowalski et al. in which chromic mud is largely recycled.

The next steps of our study were data collection and evaluation. Actually, those steps were performed simultaneously with the flow diagram drawing, but to simplify the reading, we decided to present them in a linear manner.

\section{Data collection and evaluation}

The Ecoinvent database allowed us to assess most inputs and outputs of the different life cycle steps considered here.

However, for some specific parameters that are, for example, linked to the atmospheric emissions of some processes, we used more precise data. This is the case for chromium compound emissions that we assessed using specific data related to the emission factors of processes and to the efficiency of specific control devices, given by the US EPA [17,20,21]. Results are presented in Table 4.

The energy consumption that we assessed using the Ecoinvent database [22] includes energies directly used in the process and energies used for primary material transportation. Water consumption also directly comes from the Ecoinvent database. $\mathrm{CO}_{2}$ emissions due to processes, transport and thermal and electrical energy consumptions are estimated through the use of emission factors derived from the Ecoinvent database. Specific countries' energy mixes are used when considering the electrical or thermal consumption of processes. That is why we linked each stage of the life cycle assessment to a country where the activity is considered to be carried out. For instance, some useful information coming from the International Chromium Development Association is that chromite ore is mainly extracted in South Africa, since it accounts for almost one half of world production. We then considered that chromite ore is mined in South Africa and that crushed chromite is transported to Western Europe (Germany) for chemical transformation.

Finally, precise significant flow values related to the anodizing of $10,000 \mathrm{~m}^{2}$ of aluminium are summarized in Table 5 . The environmental impacts of the different life cycle stages are also assessed, making up the final results of our LCA (see Table 6).

Table 4

Chromium compound emissions generated by chemical production processes

\begin{tabular}{llll}
\hline Process & Emission sources & $\begin{array}{l}\text { Type of chromium } \\
\text { compounds emitted }\end{array}$ & $\begin{array}{l}\text { Kg/tonne of } \\
\text { manufactured product }\end{array}$ \\
\hline Chromite ore refining & & $\operatorname{Cr}(\mathrm{III})$ & 0.001 \\
& Chromite ore dryer & $\mathrm{Cr}(\mathrm{III})$ & 0.003 \\
& Mill and cyclone & $\mathrm{Cr}(\mathrm{III})$ & 0.00005 \\
& Refined ore storage & $\mathrm{Cr}(\mathrm{III})$ & 0.00405 \\
Sodium chromate and dichromate & Total process & $\mathrm{Cr}(\mathrm{VI})$ & 0.7 \\
manufacturing plants & Kiln & $\mathrm{Cr}(\mathrm{VI})$ & 1.5 \\
Chromium trioxide manufacturing plant & Total process & $\mathrm{Cr}(\mathrm{VI})$ & 0.01 \\
& Chromic acid reactor, melter and flaker & $\mathrm{Cr}(\mathrm{VI})$ & 0.01 \\
& Filter & $\mathrm{Cr}(\mathrm{VI})$ & 0.04 \\
& Packaging & $\mathrm{Cr}(\mathrm{VI})$ & 0.06 \\
\hline
\end{tabular}


Table 5

Detailed significant flows in the chromic acid anodizing process life cycle

\begin{tabular}{|c|c|c|c|c|c|c|c|c|}
\hline & Inputs & & Outputs & & Data sources & Emissions and discharges & & Data sources \\
\hline Limestone mining & & & Limestone (calcite $\mathrm{CaCO}_{3}$ ) & $4389 \mathrm{~kg}$ & Ecoinvent & Atmospheric emissions & $0.49 \mathrm{~kg}$ & Ecoinvent \\
\hline Limestone crushing & Limestone (calcite $\mathrm{CaCO}_{3}$ ) & $4389 \mathrm{~kg}$ & Crushed limestone & $4389 \mathrm{~kg}$ & Ecoinvent & & & \\
\hline Lime production & Crushed limestone & $4389 \mathrm{~kg}$ & Lime $(\mathrm{CaO})$ & $3091 \mathrm{~kg}$ & Ecoinvent & $\begin{array}{l}\mathrm{CO}_{2} \text { emissions } \\
\text { Atmospheric emissions } \\
\text { Water discharges }\end{array}$ & $\begin{array}{l}2331 \mathrm{~kg} \\
0.15 \mathrm{~kg} \\
616 \mathrm{~kg}\end{array}$ & Ecoinvent \\
\hline Sodium chloride & & & Sodium chloride $(\mathrm{NaCl})$ & $4247 \mathrm{~kg}$ & Ecoinvent & & & \\
\hline Soda production & Lime & $2348 \mathrm{~kg}$ & Sodium carbonyle $\left(\mathrm{Na}_{2} \mathrm{CO}_{3}\right)$ & $1957 \mathrm{~kg}$ & Ecoinvent & $\begin{array}{l}\text { Calcium chloride } \\
\text { Atmospheric emissions }\end{array}$ & $\begin{array}{l}2359 \mathrm{~kg} \\
3.91 \mathrm{~kg}\end{array}$ & Kowalsky et al. \\
\hline Chromite ore mining & Sodium chloride & $2935 \mathrm{~kg}$ & Chromite ore & $2825 \mathrm{~kg}$ & $\begin{array}{l}\text { Ecoinvent \& } \\
\text { Kowalski et al. }\end{array}$ & $\begin{array}{l}\text { Water discharges } \\
\text { Atmospheric emissions (Cr (III)) }\end{array}$ & $\begin{array}{l}520 \mathrm{~kg} \\
23 \mathrm{~g}\end{array}$ & US EPA \\
\hline Sodium chromate production & Lime & $743 \mathrm{~kg}$ & Sodium chromate $\left(\mathrm{Na}_{2} \mathrm{CrO}_{4}\right)$ & $2616 \mathrm{~kg}$ & $\begin{array}{l}\text { Ecoinvent \& } \\
\text { Kowalski et al. }\end{array}$ & $\mathrm{CO}_{2}$ emissions & $3270 \mathrm{~kg}$ & Ecoinvent \\
\hline & Chromite ore & $2825 \mathrm{~kg}$ & Chromic mud & $1949 \mathrm{~kg}$ & & Chromic mud (Cr (III)) & & \\
\hline & $\begin{array}{l}\text { Sodium carbonyl } \\
\text { Chromic mud }\end{array}$ & $\begin{array}{l}1957 \mathrm{~kg} \\
7620 \mathrm{~kg}\end{array}$ & Chromic mud (recycled part) & $7620 \mathrm{~kg}$ & & & $\begin{array}{l}1949 \mathrm{~kg} \\
1.9 \mathrm{~m}^{3}\end{array}$ & Kowalsky et al. \\
\hline Sulfur production & & & Sulfur & $809 \mathrm{~kg}$ & Kowalski et al. & & & \\
\hline Sulfuric acid production & Sulfur & $809 \mathrm{~kg}$ & Sulfuric acid & $2151 \mathrm{~kg}$ & Kowalski et al. & $\begin{array}{l}\text { Atmospheric emissions } \\
\text { Water discharge }\end{array}$ & $\begin{array}{l}22 \mathrm{~kg} \\
3 \mathrm{~kg}\end{array}$ & Ecoinvent \\
\hline Hydrochloric acid production $(\mathrm{HCl})$ & Sodium chloride & $498 \mathrm{~kg}$ & Hydrochloric acid & $486 \mathrm{~kg}$ & Ecoinvent & $\begin{array}{l}\text { Atmospheric emissions } \\
\text { Water discharge }\end{array}$ & $\begin{array}{l}0.3 \mathrm{~kg} \\
18 \mathrm{~kg}\end{array}$ & Ecoinvent \\
\hline Sodium hydroxide production $(\mathrm{NaOH})$ & Sodium chloride & $814 \mathrm{~kg}$ & Sodium hydroxide $(\mathrm{NaOH})$ & $1005 \mathrm{~kg}$ & Ecoinvent & & & \\
\hline Sodium dichromate production & $\begin{array}{l}\text { Sodium chromate } \\
\left(\mathrm{Na}_{2} \mathrm{Cr}_{2} \mathrm{O}_{4}\right)\end{array}$ & $2616 \mathrm{~kg}$ & Sodium dichromate $\left(\mathrm{Na}_{2} \mathrm{Cr}_{2} \mathrm{O}_{7}\right)$ & $1767 \mathrm{~kg}$ & $\begin{array}{l}\text { Ecoinvent } \\
\text { database \& }\end{array}$ & Water discharge $(\mathrm{Cr}(\mathrm{VI}))$ & $\begin{array}{l}59 \mathrm{~kg} \\
1.64 \mathrm{~m}^{3}\end{array}$ & Kowalsky et al. \\
\hline & Sulfuric acid & $725 \mathrm{~kg}$ & Chromic sodium sulfate & $566 \mathrm{~kg}$ & Kowalski et al. & $\begin{array}{l}\text { Atmospheric } \\
\text { emissions }(\mathrm{Cr}(\mathrm{VI}))\end{array}$ & $265 \mathrm{~g}$ & US EPA \\
\hline Chromium trioxide production & Sodium dichromate & $1767 \mathrm{~kg}$ & Chromium trioxide $(\mathrm{Cr}(\mathrm{VI}))$ & $1319 \mathrm{~kg}$ & $\begin{array}{l}\text { Ecoinvent \& } \\
\text { Kowalski et al. }\end{array}$ & Liquid wastes $(\mathrm{Cr}(\mathrm{VI}))$ & $\begin{array}{l}92 \mathrm{~kg} \\
2.56 \mathrm{~m}^{3}\end{array}$ & Kowalsky et al. \\
\hline & Sulfuric acid & $1319 \mathrm{~kg}$ & Chromic sodium sulfate & $686 \mathrm{~kg}$ & & $\begin{array}{l}\text { Atmospheric emissions } \\
\text { Water discharge }\end{array}$ & $\begin{array}{l}2.64 \mathrm{~kg} \\
28.79 \mathrm{~kg}\end{array}$ & Ecoinvent \\
\hline Sodium sulfate production & Chromic sulfate sodium & $1251 \mathrm{~kg}$ & Sodium sulfate $\left(\mathrm{Na}_{2} \mathrm{SO}_{4}\right)$ & $1189 \mathrm{~kg}$ & Kowalski et al. & $\begin{array}{l}\text { Atmospheric emissions }(\mathrm{Cr}(\mathrm{VI})) \\
\text { Liquid wastes }(\mathrm{Cr}(\mathrm{VI}))\end{array}$ & $\begin{array}{l}79 \mathrm{~kg} \\
51 \mathrm{~kg} \\
1.42 \mathrm{~m}^{3}\end{array}$ & $\begin{array}{l}\text { US EPA } \\
\text { Kowalsky et al. }\end{array}$ \\
\hline Aluminum anodizing & $\begin{array}{l}\text { Chromium trioxide } \\
\text { Sodium hydroxide }(\mathrm{NaOH}) \\
\text { Sulfuric acid }\left(\mathrm{H}_{2} \mathrm{SO}_{4}\right) \\
\text { Hydrochloric acid }(\mathrm{HCl})\end{array}$ & $\begin{array}{l}1319 \mathrm{~kg} \\
1005 \mathrm{~kg} \\
108 \mathrm{~kg} \\
486 \mathrm{~kg}\end{array}$ & Anodized aluminum & $10,000 \mathrm{~m}^{2}$ & Harscoët & $\begin{array}{l}\text { Water discharge } \\
\text { Liquid wastes }(\mathrm{Cr}(\mathrm{VI}))\end{array}$ & $\begin{array}{l}31 \mathrm{~kg} \\
1319 \mathrm{~kg} \\
37 \mathrm{~m}^{3} \\
142 \mathrm{~g}\end{array}$ & Harscoët \\
\hline $\begin{array}{l}\text { Waste treatment (chrome }(\mathrm{VI}) \text { to } \\
\text { chrome (III) reduction) }\end{array}$ & Liquid wastes (Cr (VI)) & $1521 \mathrm{~kg}$ & Chrome III & $1521 \mathrm{~kg}$ & Kowalski et al. & Water discharge & $0.28 \mathrm{~kg}$ & Ecoinvent \\
\hline Final disposal & $\begin{array}{l}\text { Liquid wastes }(\mathrm{Cr}(\mathrm{III})) \\
\text { Chromic mud }\end{array}$ & $\begin{array}{l}1521 \mathrm{~kg} \\
1949 \mathrm{~kg}\end{array}$ & & & & & & \\
\hline
\end{tabular}

Functional unit: $10,000 \mathrm{~m}^{2}$ of anodized aluminium. 
Table 6

Environmental impacts incurred during the life cycle of a CAA process

\begin{tabular}{|c|c|c|c|c|c|c|c|c|c|c|c|c|c|}
\hline & \multicolumn{3}{|c|}{ Energy consumptions (MJ) } & \multirow{2}{*}{$\begin{array}{l}\text { Natural } \\
\text { resources } \\
\text { consumption }(\mathrm{kg})\end{array}$} & \multirow{2}{*}{$\begin{array}{l}\text { Water } \\
\text { consumption } \\
\left(\mathrm{m}^{3}\right)\end{array}$} & \multicolumn{3}{|c|}{$\mathrm{CO}_{2}$ emissions $(\mathrm{kg})$} & \multirow{2}{*}{$\begin{array}{l}\text { Wastes } \\
\text { generated } \\
(\mathrm{kg})\end{array}$} & \multirow{2}{*}{$\begin{array}{l}\mathrm{Cr}(\mathrm{VI}) \\
\text { atmospheric } \\
\text { emissions }(\mathrm{g})\end{array}$} & \multirow{2}{*}{$\begin{array}{l}\mathrm{Cr}(\mathrm{VI}) \text { water } \\
\text { discharge } \\
(\mathrm{kg}) \\
\end{array}$} & \multirow{2}{*}{$\begin{array}{l}\text { Other } \\
\text { atmospheric } \\
\text { emissions (kg) }\end{array}$} & \multirow{2}{*}{$\begin{array}{l}\text { Other water } \\
\text { discharges } \\
(\mathrm{kg})\end{array}$} \\
\hline & Electricity & Thermal & Transport & & & Process & Energy & Transport & & & & & \\
\hline Limestone mining & 0 & 82 & 0 & 0 & 0.00 & 0 & 5 & 0 & 0 & 0 & 0 & 0.49 & 0 \\
\hline Limestone crushing & 11 & 18 & 0 & 0 & 0.00 & 0 & 3 & 0 & 0 & 0 & 0 & 0 & 0 \\
\hline Lime production & 1001 & 4919 & 24 & 4389 & 1.86 & 2331 & 507 & 10 & 0 & 0 & 0 & 0.15 & 616.01 \\
\hline Sodium chloride production & 1024 & 1436 & 157 & 0 & 16.22 & 0 & 277 & 128 & 0 & 0 & 0 & 0 & 0 \\
\hline Soda production & 282 & 14,127 & 3707 & 2935 & 99.88 & 0 & 996 & 3385 & 2359 & 0 & 0 & 3.91 & 520.08 \\
\hline Chromite ore mining & 380 & 228 & 0 & 0 & 7.60 & 0 & 115 & 0 & 0 & 0 & 0 & 22.74 & 0 \\
\hline Sodium chromate production & 565 & 20,927 & 0 & 2825 & 0.00 & 3270 & 1501 & 0 & 1949 & 0 & 0 & 0 & 0 \\
\hline Sulfur production & 102 & 3193 & 0 & 0 & 3.64 & 0 & 232 & 0 & 0 & 0 & 0 & 0 & 0 \\
\hline Sulfuric acid production & 135 & 7 & 1168 & 809 & 104.98 & 0 & 24 & 957 & 0 & 0 & 0 & 21.75 & 2.93 \\
\hline $\begin{array}{l}\text { Hydrochloric acid } \\
\text { production }(\mathrm{HCl})\end{array}$ & 55 & 840 & 512 & 498 & 6.39 & 0 & 66 & 420 & 0 & 0 & 0 & 0.33 & 18.07 \\
\hline $\begin{array}{l}\text { Sodium hydroxide } \\
\text { production }(\mathrm{NaOH})\end{array}$ & 5243 & 0 & 147 & 814 & 47.39 & 0 & 929 & 111 & 0 & 0 & 0 & 0.26 & 11.63 \\
\hline Sodium dichromate production & 1144 & 42,419 & 13,476 & 0 & 53.02 & 0 & 3043 & 7771 & 1215 & 265 & 0 & 0 & 0 \\
\hline Chromium trioxide production & 1580 & 2638 & 4263 & 0 & 39.57 & 0 & 457 & 3493 & 1894 & 79 & 13.08 & 2.64 & 28.79 \\
\hline Sodium sulfate production & 1424 & 2378 & 0 & 0 & 0.00 & 0 & 412 & 0 & 1050 & 0 & 0 & 0 & 30.67 \\
\hline Aluminium anodizing & $1,26,252$ & $8,85,530$ & 0 & & 134.90 & 0 & 61,049 & 0 & 36,786 & 142 & 0 & 0 & 0 \\
\hline $\begin{array}{l}\text { Waste treatment (chrome VI } \\
\text { to chrome III reduction) }\end{array}$ & 31 & 6 & 0 & 0 & 0.00 & 0 & 1 & 0 & 0 & 0 & 0.28 & 0 & 0.28 \\
\hline Final disposal & 0 & 21,322 & 2431 & 0 & 0.00 & 0 & 1428 & 1893 & 0 & 0 & 0 & 0 & 0 \\
\hline TOTAL (With anodizing) & $1,39,228$ & $\begin{array}{l}10,00,068 \\
11,65,181\end{array}$ & 25,885 & 12,270 & 515 & 5600 & $\begin{array}{l}71,043 \\
94,810\end{array}$ & 18,167 & 45,254 & 487 & 13 & 52 & 1228 \\
\hline TOTAL (without anodizing) & 12,976 & $\begin{array}{l}1,14,538 \\
1,53,399\end{array}$ & 25,885 & 12,270 & 381 & 5600 & $\begin{array}{r}9995 \\
33,762\end{array}$ & 18,167 & 8467 & 344 & 13 & 52 & 1228 \\
\hline
\end{tabular}

Functional unit: $10,000 \mathrm{~m}^{2}$ of anodized aluminium. 


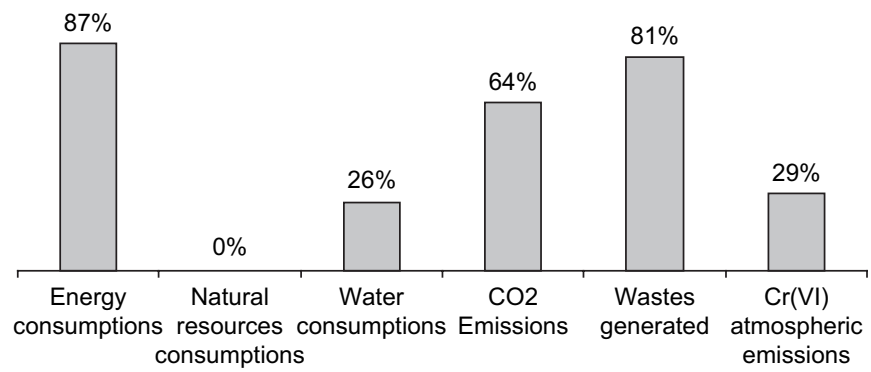

Fig. 6. Contribution of the anodizing stage to global life cycle environmental impacts.

\section{Results review and discussion}

The first result that must be indicated is the large contribution of the anodizing stage to the environmental impacts of the whole life cycle (see Fig. 5). This point seems quite logical as the treatment of $10,000 \mathrm{~m}^{2}$ of aluminium requires that roughly $1300 \mathrm{~kg}$ of chromium trioxide stay within the firm perimeter for a long time (more than a month) during which time energy, water and other resources are consumed. Compared to this time period, the time needed to manufacture the compound is undoubtedly smaller, which may explain why the anodizing phase (the use stage) highly contributes to the environmental impacts. Note that the overall treatment capacity of the bath during its lifetime is greater than the functional unit considered here $\left(10,000 \mathrm{~m}^{2}\right)$, which means that the quantity of $\mathrm{CrO}_{3}$ initially used to set up the bath in our study was allocated proportionally to its total treatment capacity. This last comment does not concern chemicals consumptions to compensate drag outs as they are directly linked to the quantity of aluminium treated.

Fig. 6, however, shows that impact of the anodizing phase can be separated in two distinct categories.

- Firstly, the major impacts of the process are clearly energy consumed and wastes generated. The quantity of $\mathrm{CO}_{2}$ emitted during this stage is, moreover, almost totally generated by on-site natural gas combustion as in our assessment the transportation of primary and auxiliary material in this stage does not constitute a significant flow and is, therefore, not assessed. The fact that aluminium anodizing contributes to more than $79 \%$ of the total quantity of waste
Energy consumptions

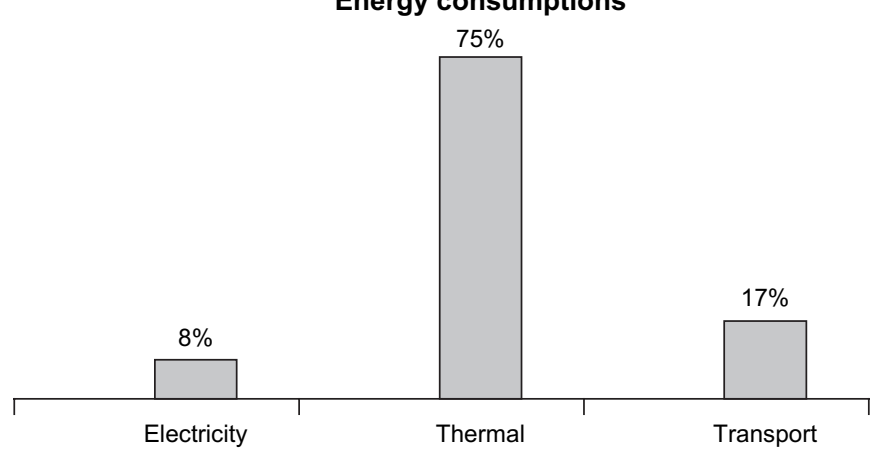

Fig. 7. Energy consumption classified by source when the anodizing stage is not included.

generated during the whole life cycle is once again not surprising as the whole quantity of chemical mixed with water to form the electrolyte in the bath constitutes waste when quality requirements are no longer fulfilled. Again, the quantity of waste generated was allocated proportionally to the overall treatment capacity of the bath during its lifetime.

- Secondly, some results may be considered as being representative of the good performance of the considered process regarding some environmental issues. It is indeed clear that when this stage's global contribution to the environmental impacts is compared with the whole life cycle, water consumption and hexavalent chromium atmospheric emissions represent a relatively small amount. This is particularly true for water consumption whose level shows that the water recycling process using ionic exchange resins is a very efficient one. We can also assume that the air treatment system used is nearly the most efficient one that exists. Reducing the $\mathrm{Cr}(\mathrm{VI})$ emitted would then require the use of a different chemical as the electrolyte in the bath.

To have a closer look to the results, we consider the other stages of the life cycle independently from the anodizing process.

Fig. 7 shows that when the anodizing stage is not considered, energy consumption is mostly due to thermal energy consumption as it represents $75 \%$ of total amount. More

Thermal energy consumptions

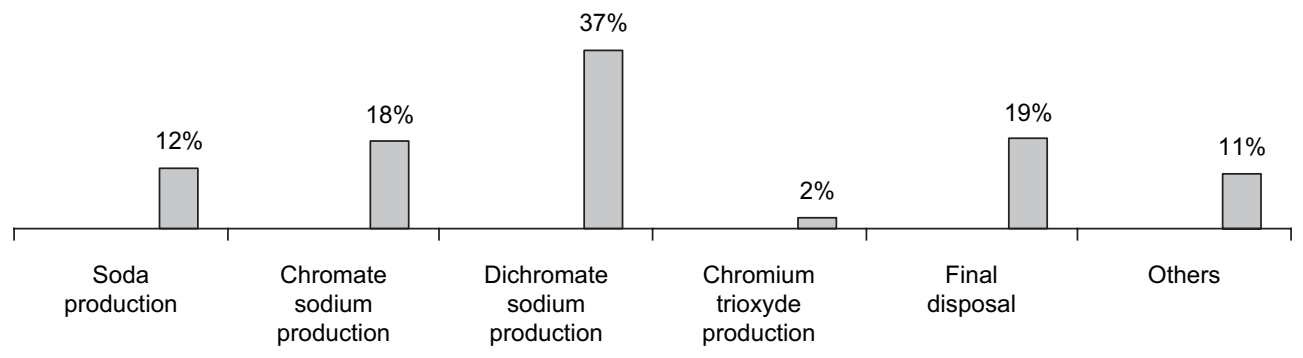

Fig. 8. Energy consumption classified by stage when the anodizing stage is not included. 


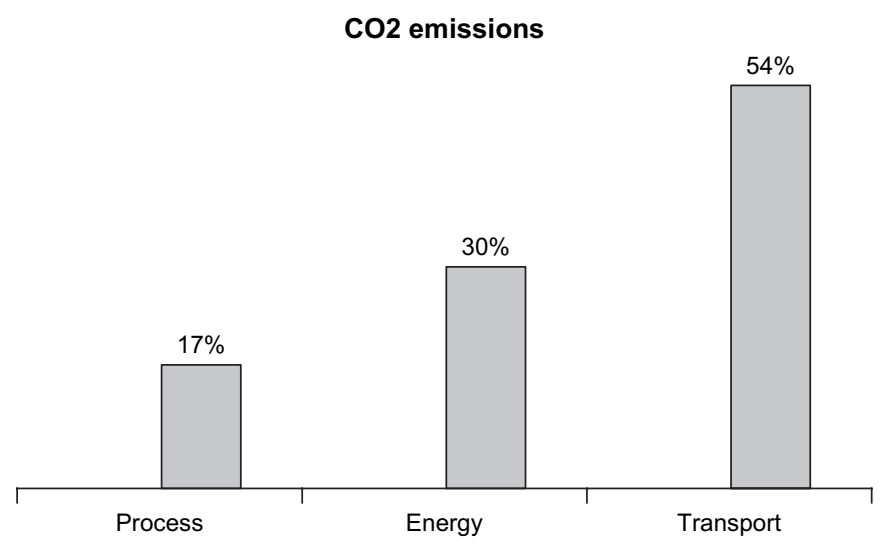

Fig. 9. $\mathrm{CO}_{2}$ emissions classified by source when the anodizing stage is not included.

precisely, $71 \%$ of thermal energy consumption is due to chemical production (soda, chromate and dichromate sodium, chromium trioxide) whereas $19 \%$ is due to the final waste disposal process (Fig. 8). As shown in Fig. 9, when the main stage is not accounted for, $\mathrm{CO}_{2}$ emissions mainly come from transportation and when we examine the precise steps that require important amounts of energy for transportation, we see that soda, sulfuric acid, sodium chromate, sodium dichromate and chromium trioxide production represents almost $70 \%$ of $\mathrm{CO}_{2}$ emissions due to transportation activities. This can be explained by the fact that those production processes may require natural resources that have to be extracted in a country located far away. Note that transportation needs for chromate and dichromate sodium production processes are considered together in the dichromate sodium production stage as in our model we consider that those two chemicals are produced by the same firm. It is also important to note that those production processes represent $52 \%$ of the total amount of the $\mathrm{CO}_{2}$ emitted by transportation, which is explained by the use of chromite ore mainly extracted in South Africa for the production process occurring in Europe. Finally, Fig. 10 shows that water consumption for sulfuric acid, sodium dichromate and chromium trioxide contributes highly to total water consumption. More precisely, they represent $87 \%$ of the life cycle amount when water consumed during aluminium anodizing is not included. Once again, the chromate and dichromate sodium processes are considered together.

\section{Conclusions}

First, a performance improvement in the anodizing process considered here should concern both the energy consumption and waste generation environmental aspects. When considering waste, a double dividend may be generated for the firm by increasing the treatment bath lifetime. Indeed, if such a goal is reached, on the one hand, less used baths would have to be disposed of so external treatment costs could be lowered, and on the other hand, less new baths would have to be set up and this would lead to a direct decrease in various purchase costs.

Regarding $\mathrm{Cr}(\mathrm{VI})$ emissions, it seems that they cannot easily be reduced. Moreover, when the whole life cycle is taken into account, the amount emitted during the anodizing stage can be considered as quite low, so that the global efficiency of any local action taken on such a surface treatment site already using a high performance air treatment process would not be particularly worthwhile. The only way to efficiently deal with this issue would be to use another chemical in the process, so that $\mathrm{Cr}(\mathrm{VI})$ emissions are totally removed.

However, when considering substitution for the hexavalent chromium, the environmental performance in terms of energy and waste of the alternatives processes using safer chemicals should be carefully monitored to ensure improvement or no deterioration in these areas. That is why when shifting to a less toxic electrolyte, the operating temperature of the new bath should ideally be lower than the one used for the previous process so that energy consumption could be reduced. At the same time, $\mathrm{CO}_{2}$ emissions would be decreased. The fact that some raw materials come from far away could also be taken into account when considering the climate change issue. When choosing the substitute, the fact that some processes consuming a large amount of water may be required to produce the new chemical employed has also to be closely looked at, to ensure that the performance regarding this issue is not deteriorated.

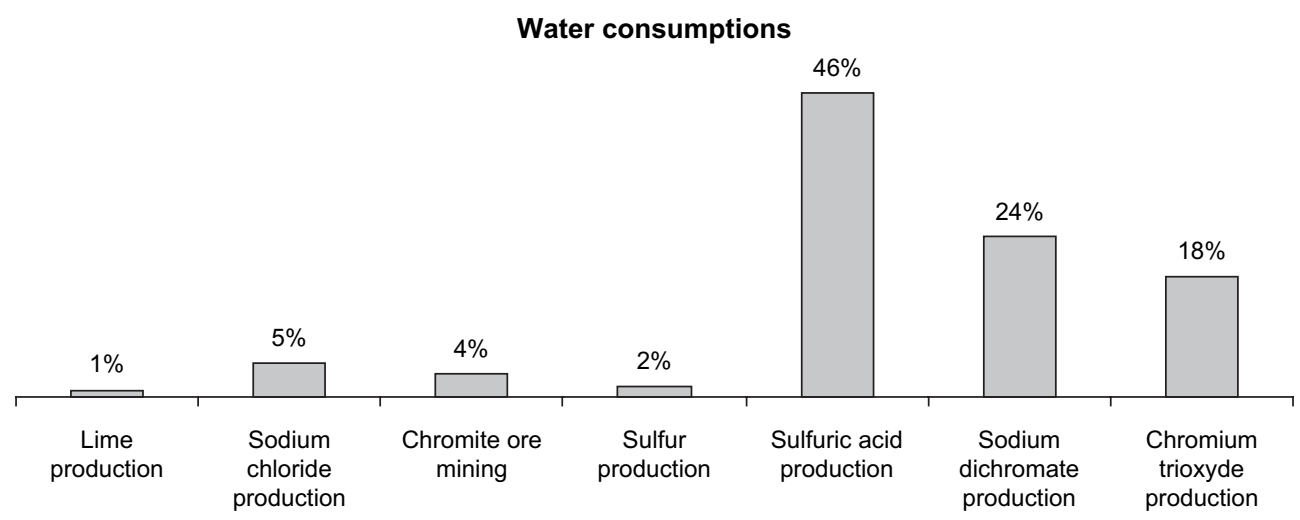

Fig. 10. Water consumptions classified by phase when the anodizing stage is not included. 
To get an idea of the existing ways to technically increase environmental performance, the European Commission's BREF document can be consulted [6].

We finally point out that so-called simplified approaches for life cycle assessment provide data that are reliable enough for businesses to formulate their environmental strategies.

\section{Acknowledgments}

We would like to thank every people involved in our project for their valuable contribution to the research and data collection. For confidentiality reasons we, however, do not name them directly.

\section{References}

[1] SETAC. Guidelines for life cycle assessment: a "code of practice" Brussels: Society of Environmental Toxicology and Chemistry; 1993.

[2] Heijungs R. Identification of key issues for further investigation in improving the reliability of life cycle assessments. Journal of Cleaner Production 1996;4(3-4):159-66.

[3] ISO. ISO 14040 environmental management - life cycle assessment principles and frame work. NF EN ISO 14040

[4] Benetto E. Analyse du Cycle de Vie: Réalisation de l'inventaire. Technique de l'ingénieur 2000;G 5:510.

[5] Le Pochat S. Intégration de l'Eco-conception dans les PME: Proposition d'une méthode d'appropriation de savoir-faire pour la conception environnementale des produits. PhD thesis, ENSAM; 2005.

[6] EC. BREF - reference document on best available techniques for the surface treatment of metals and plastics; 2005.

[7] Hur T, Lee J, Ryu J, Kwon E. Simplified LCA and matrix methods in identifying the environmental aspects of a product system. Journal of Environmental Management 2005;75.

[8] Janin M. Démarche d'éco-conception en entreprise; Un enjeu: construire la cohérence entre outils et processus. PhD thesis, ENSAM; 2000.
[9] Blouet A, Rivoire E. L'écobilan, les produits et leurs impacts sur l'environnement. Dunod edition; 1995, ISBN 2-10-002126-5.

[10] Khalifa K. Analyse du cycle de vie - Problématique de l'évaluation des impacts. Techniques de 1'Ingénieur 1999;G 5:610.

[11] Kincaid E, Geibig JR. Printed wiring board cleaner technologies substitutes assessment: making holes conductive. Design for the environment US EPA program; 1998.

[12] Burgess WH. Recognition of health hazards in industry: a review of materials and processes. New York: John Wiley and Sons; 1981.

[13] Berglund R, Lindh E. Prediction of the mist emission rate from plating baths. Göteberg: Swedish Institute of Production Engineering Research; 1988.

[14] Cooper CD, Wayson RL, Dietz JD, Bauman D, Cheze K, Sutch PJ. Atmospheric releases of formaldehyde from electroless copper plating operations. Proceedings of the eightieth AESF annual technical conference, Anaheim, CA, 1993.

[15] Kuo YM, Wang CS. Effect of rise distance on droplets generated from bubble bursting on the surface of chromic acid solutions. AIHA Journal American Industrial Hygiene Association 2002.

[16] Pegman RC, Pilat M. Airborne particulate emissions from a chromic acid anodizing process tank. Journal of the Air and Waste Management Association $1992 ; 42(3)$

[17] US EPA. Compilation of air pollutant emission factors - AP42. Environmental Protection Agency; 1996.

[18] INRS. Cuves de traitement de surface: Performance de captage des fentes d'aspiration. ND 2030; 1996.

[19] INRS. Cuves de traitement de surface: Le guide pratique de ventilation $\mathrm{n}^{\circ} 2$. ED 651; 2001.

[20] US EPA. Locating and estimating air emissions sources of chromium. EPA-450/4-84-007g. Office of Air Radiation; 1984.

[21] US EPA. Locating and estimating air emissions sources of chromium (Supplement). Office of Air Radiation; 1989. EPA-450/2-89-002.

[22] Ecoinvent, www.ecoinvent.ch.

[23] Frischknecht R, Jungbluth N, Althaus H, Doka G, Dones R, Heck T, et al. The ecoinvent database: overview and methodological framework. International Journal of Life Cycle Assessment 2005;10(1):3-9 [Online publication, 2004].

[24] Kowalsky Z, Kulczycka J, Wzorek Z. Life cycle assessment of different variants of sodium chromate production in Poland. Journal of Cleaner Production 2005. 